\title{
A SOCIOLOGICAL, NEUROLOGICAL, SEROLOGICAL AND PSYCHIATRICAL STUDY OF A GROUP OF PROSTITUTES.*
}

\author{
BY DR. JAU DON BALL AND DR. HAYWARD G. THOMAS, \\ Oakmand, California.
}

The following report is the result of a study of 320 prostitutes in the city of San Francisco, California. This study was undertaken by the Neurological and Psychiatrical and Ophthalmological Department of the Oakland College of Medicine and Surgery, Oakland, California, by Dr. J. D. Ball, Professor of Mental and Nervous Diseases, assisted by Dr. Paul Jerome Anderson, Oakland College of Medicine and Surgery; Dr. Hayward G. Thomas, Professor of Ophthalmology, the same college; and with the assistance of Mr. August Vollmer, Chief of Police, Berkeley, California, and with the sanction and assistance of the San Francisco Police Department. Great credit is due to Chief White of San Francisco Police Department, whose cooperation and interest in the investigation made the work possible, and certainly less difficult than it otherwise would have been.

The investigation lasted during a period of 18 months, from August, 1915, to March, 1917, and was unusual in approach, for the reason that all examinations were made in the houses of prostitution during the "working" hours. This was thought to be the best method, as environmental conditions were normal for the work at hand; the inmates being at their "best" and not under the restraint incident to examinations made in institutions or psychological laboratories in connection with courts. Unusual and detracting environmental conditions and emotional states were thus considered eliminated to a large degree. In all, 45 trips were made; 66 houses of prostitution visited; 270 hours or 33 ? days of eight hours' actual time, spent in interviews and examinations.

The expense of this investigation, including laboratory work, was borne by the investigators.

\footnotetext{
* Read at the seventy-third annual meeting of the American MedicoPsychological Association, New York, May 29-June 1, 1917.
} 
The reason for this study being a desire to contribute the data and information so obtained in the hope that it might be of value not only in stimulating similar studies, especially from the neurological and psychiatrical standpoint; but in aiding sociologists and others interested in the great social problem of prostitution to a clearer understanding of a few of its causes. The data obtained are presented for what they are worth, and their value lies in the fact that they are the result of unbiased investigation and examination. No preconceived ideas as to possible results were formed; and the personal equation of the examiner (especially regarding any fads, fancies, or fanaticisms relative to his own particular specialty, had he possessed any such) was eliminated as far as possible.

The facts resulting from careful examinations are thus presented to you without any hesitation or mental reservation. Whatever notions or secret ideas any of us might have held regarding this subject were dispelled by the facts obtained.

\section{Methods of Examination.}

The following form was used in this examination. Some very valuable suggestions were obtained from Dr. Healy's Individual Delinquent.

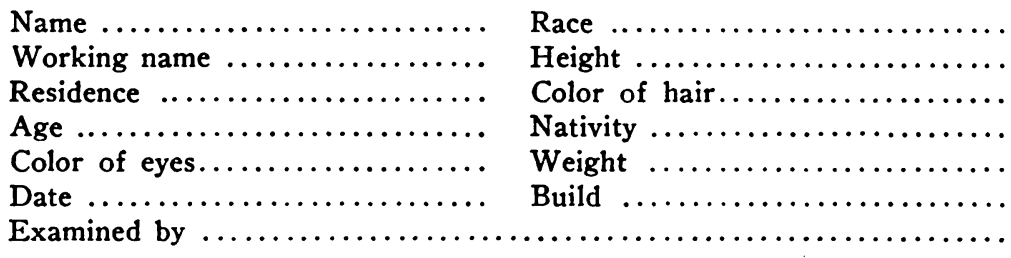

HEREDITY.

Maternal grandfather

Maternal grandmother

Paternal grandfather

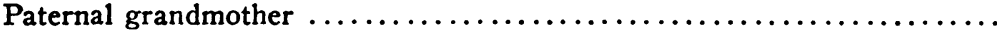

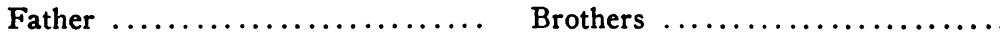

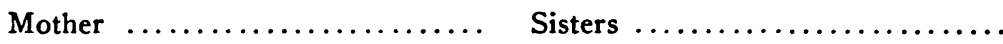

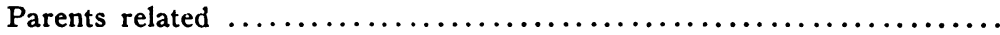

Mental ....... Nervous ..... Ep E Elepsy ...... Bright's disease ..

Diabetes ...... Syphilis ....... Eruptions ..... Cancer .........

Rheumatism ... Chorea ........ 
Health History inctuding History of Infancy and Chindhood.

Diseases of childhood, adolescence, and adult life, especially convulsion or disturbances of consciousness.

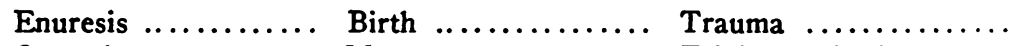
Operations ......... Menses ........... Fright or shock....... Adolescent instabilities or peculiarities, both mental and physical........

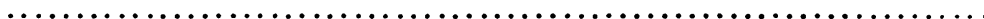

Comparison of development with other members of the family.

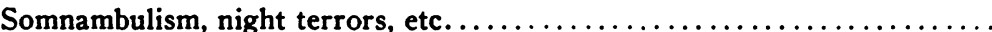
........................................................

\section{Socrological Examination.}

Housing and financial conditions in detail.

Occupation of father.

Reasons for leaving home.

Whether raised in city or country Companionship; opportunities afforded by relatively good or bad association

Amusements in detail

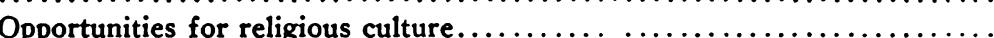

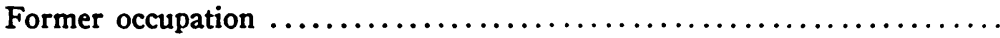

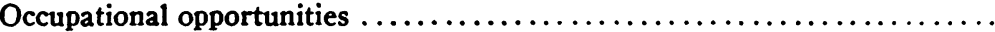

Character of places worked in.

Married ....... Single ........ Widow ........ Divorced....... If married, complete history of home life.

Miscarriages ........ Still-born children ...... Children ........

Mental and Moral Development.

School history in detail, with individual's own reaction toward it.........

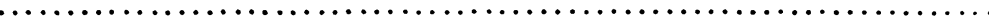

Education

Grade reached

Much absence Character of association with opposite sex. Habits : Drug...... Alcohol ...... Tobacco ...... Sexual.......

\footnotetext{
ADDENDA.

At what age enter sporting life. Reasons for entering sporting life. Unsatisfied interests
} 
Types of Perverts Met with.

\section{Mental Examination.}

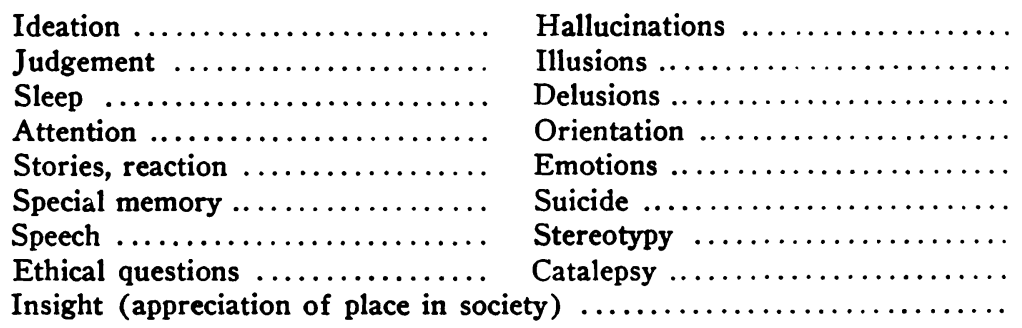

Neurological Examination.

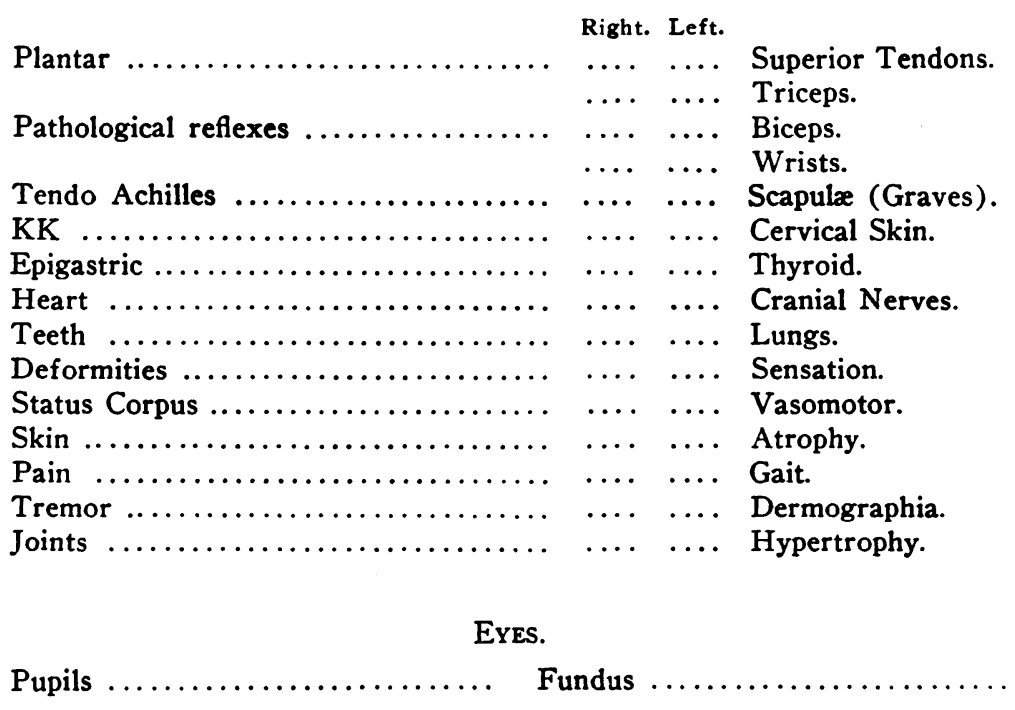

\section{General InFormation.}

Accompanied by a sergeant of police in plain clothes, we entered the houses of prostitution where the "madames" were informed of the nature and object of our visit. At no time were we met with antagonism and distrust. Every facility and assistance was 
offered by the "madames," and after the inmates ascertained individually the reason for the interruption of their work, they entered into the spirit of the investigation with a manner most pleasing and willing. Occasionally, however, an individual would be encountered who would be grossly excited or emotionally negative, and it would take considerable time to gain her consent for examination. Where such negativism was encountered, it was usually the result of fear engendered in the individual by either vague rumors concerning our methods or by lies told by those already examined, having as an object to frighten the subject, often as a " joke," or a manifestation of a psychosis. In quieting these individuals we were invariably assisted by their less emotional sisters.

Each examiner had a room where he was alone with the subject. The order of the examination was:

Ist. The taking of blood for subsequent serological examination.

2d. History taking, and general sociological and educational examination.

3d. Psychiatrical examination.

4th. Neurological examination.

5th. Physical examination.

6th. Ophthalmological examination.

The reason for the taking of the blood, for serological examination, first, was to eliminate at once the fear of the taking of the blood, which we early found to be a distracting factor if left to the last.

The form above given and used in this investigation gives an idea of the extent of this research. However, many questions were asked which are not included in the form, and were necessitated by the individual cases to obtain a correct sociological and psychiatrical impression.

Also, after the conclusion of the examination of a group for the evening, the examiners would spend at least forty minutes, sometimes an hour, discussing the cases examined. This was especially valuable, as by it they were enabled to digest the impressions of each other regarding the individuals studied.

Of special interest to this organization will be the results of the serological, neurological, ophthalmological and psychiatrical examinations. 


\section{A. Serological Data.}

Original Wassermann method was used, ${ }^{1}$ occasionally results being checked by other laboratories, all sera being run along with sera from private patients.

Needles were specially prepared and sterilized and placed in specially prepared and sterilized test-tubes until used, the testtubes being used to collect the blood. Therefore, no boiling of needles was necessary in the houses, each subject having individual needle and tube.

Seventy-four per cent of the total number of 320 had positive Wassermann reaction with blood serum; 3 per cent gave a negative Wassermann reaction; and 23 per cent admitted having had syphilis or were under active treatment for the disease.

\section{B. Neurological Data.}

It has been the custom, only too often, not alone by the general physician but also by the neurologist, to pass lightly over a slightly exaggerated or a slightly diminished, or even retarded reflex.

If a reflex is greatly exaggerated, or very sluggish, or absent, it is so recorded. The finer degrees of variation from the normal are seldom recognized and certainly infrequently recorded.

This brings up the question of what is the normal response of a deep or a superficial reflex. In the clinic of the Neurological Department of the Oakland College of Medicine and Surgery, it has been the custom, since I9I 3 , to use an arbitrary method of recording reflexes, as follows:

Normal is considered the reaction as a result of a stimulus applied always in the same manner and with the same degree of intensity ; and of necessity, for clinical purposes, must be taken into consideration the personal equation of the clinician.

Experiments have been conducted and time reactions developed for the various reflexes; but as yet the practical application of these methods is distant, especially where time is a factor. Accordingly, a system of recording reflexes ought to be adopted that will at least be more or less universally used, even though the personal equation of the clinician does enter.

For our purposes we have used $N$ for normal, and decimals of five up to twenty, either plus or minus, for exaggerated or diminished reflexes, and o (zero) for absent reflexes. For example: 
A normal $\mathrm{KK}$ in our conception is the response of the jerk to a blow from a hammer always of the same size and weight, and applied always with the same force. By experience it is learned that a jerk of a certain amplitude will take place normally as a result of the application of the stimulus under same conditions.

If there is an increase in the quickness of the response of the jerk to the usual stimulus, this is measured in degrees as +5 , $+10,+15$, or +20 and might be further explained as follows: Slightly exaggerated, exaggerated, greatly exaggerated, and very greatly exaggerated (the latter approaching a leg clonus or the greatest possible increase from the least possible stimulus). If there is a decrease in the quickness of the response of the jerk to the usual stimulus, it is recorded in degrees as $-5,-10,-15$, -20 , or 0 , and in language can be designated as slightly diminished, diminished or sluggish, greatly diminished, very greatly diminished, and absent. (A very greatly diminished reflex being the least possible response to the greatest possible stimulus.)

This method can be applied to all of the deep and superficial reflexes, and gives an arbitrary method of recording degrees of responses of the various reflexes.

No originality is claimed for this method except that it was developed in the above-mentioned clinic, and a plea is made for the adoption of some standard for recording reflex data. Later it was ascertained that Dr. Sheldon of the Neurological Department of the Mayo Clinic, in Rochester, Minnesota, was using a similar method of recording his neurological observations. Only he used multiples of $I, 2,3,4$. Just how long he has been using this method, I do not know.

Ninety-seven per cent of these women manifested either pathological or perverted reflexes or sensory disturbance.

The scapulæ of 270 cases were examined. One hundred and sixty-seven were found to be scaphoid ("scaphoid scapulæ, Graves "), fifty-three straight and fifty normal.

An exhaustive neurological analysis cannot be made in this report; but enough is given to demonstrate that all syphilitics are liable to perversion of their reflexes, and that not enough attention has heretofore been paid to slight differences in quantity and quality of reflex action, especially in those individuals denying a luetic infection or being unconscious of it ; such points as disproportion hetween reflexes are also often entirely overlooked. 


\section{Psychiatrical Data.}

From the form used in this investigation, it will be seen that a fair mental examination was conducted.

This examination also considers as far as possible the "makeup " of the individual, and also included the mental status, which was ascertained by leading the individual under examination into a general conversation and gradually drawing out any peculiar ideas or observing deficiency of general intelligence, not here entering into a discussion of the psychological problem of whether an individual may have general intelligence but rather using it to indicate a normal individual, as psychiatrists understand that conception.

By that same method, the degree of mental intelligence was ascertained.

Occasionally a Binet-Simon test was made on an unselected individual and in such cases either feeble-minded or subnormal, were defined.

A friendly feeling was first established between the investigator and the subject under investigation, and as the conversation progressed, a few direct questions were thrown in, and the degree of intelligence, memory for recent and past events, family history, personal history, data of life, general knowledge, such as calculation, writing, retention, were ascertained. Much was learned from the general attitude and manner, facial expression, speech, emotional responsiveness, and replies to ethical questions.

At no time did we find any fully developed major psychoses. However, we did find types such as manic-depressive, dementia præcox, and hysterical.

The number of manic-depressive was small (and the symptoms were mainly brought out when the subject was under the influence of alcohol or drugs, at such time the subject stating she was either greatly excited or severely depressed, more often depressed and suicidal), usually with history of abnormally long periods of mild depression or excitement preceding or following alcoholic or drug indulgence.

The dementia-præcox types were ascertained by eye-ground findings in association with results of general mental, neurological and physical examination.

The number of manic-depressive types so found was 64 or 20 per cent. 
The number of dementia præcox was 123 or 38.4 per cent.

The number of hysterical, 19 or 5.9 per cent.

The remainder, I 44 cases, we considered subnormal or defective mentally without manifesting any indications of a psychosis. The number having attempted suicide was 35 or 10.9 per cent. One had attempted suicide three times and one, twice.

\section{Sociological Data.}

By sociological data we mean particularly sociological causes, if there can be such, of prostitution, with especial reference to this group. Here, we do not assume that the science of sociology treats of " social evils and their remedies," but rather looking at it as Elwood has well stated as "social evils being incidental in normal social evolution."

Nor have we lost sight of the biological aspect of the subject.

\begin{tabular}{|c|c|}
\hline \multicolumn{2}{|c|}{ NATIONALITIES. } \\
\hline untry. & Number. \\
\hline France & Sweden \\
\hline America & Irish-American \\
\hline Germany $\ldots \ldots \ldots \ldots \ldots \ldots \ldots, 43$ & Austria \\
\hline$\ldots \ldots 30$ & Poland \\
\hline Jews of all nations... & Belgium \\
\hline England $\ldots \ldots \ldots \ldots$ & Denmark ............... 2 \\
\hline Scotland $\ldots \ldots \ldots \ldots \ldots \ldots \ldots$ I7 & American Indian (half breed). \\
\hline Mexico-Spanish (half breeds).. I6 & Holland...$\ldots \ldots \ldots \ldots$ \\
\hline Scotch-Irish & Roumania $\ldots \ldots \ldots \ldots \ldots$ \\
\hline aly & Finland \\
\hline$\ldots \ldots \ldots \ldots$ & Unknown \\
\hline & \\
\hline
\end{tabular}

By "country" is meant that the individual was born in the country indicated, or the parents were natives of that country.

\section{OCCUPATION OF FATHER.}

It is interesting to study the following table of Occupation of Fathers of this group of prostitutes. On close analysis it is found that the largest number of fathers were farmers ( 12 per cent). Next in order we have carpenters (3.75 per cent); then saloonkeepers (3.25 per cent); then tailors and barbers (each 2.5 per cent); then clerks ( 2 per cent). 
Among the fathers, we find seven physicians; two lawyers; ten each of contractors and tailors; seven each of laborers and railroad employees; six each of merchants, miners, musicians, and steam engineers ; five each of stone masons, blacksmiths, and innkeepers; four each of barbers, enlisted army men; three each of grocers, painters, lumbermen, plumbers, electricians, and shoemakers; two each of school teachers, millers, clergymen, brewers, teamsters, jewelers, sailors, mechanics, and civil engineers; and one each of shoe manufacturer, potter, dairyman, salesman, gardener, printer, baker. factory-worker, moulder, bank clerk, artificial flower maker, draughtsman, tanner, bank cashier, peddler, scavenger, architect, government clerk, bookbinder, furrier, chef, broker, piano maker, tent-maker, bricklayer, newspaper reporter, and grain tester. The balance did not know occupation of father or for some reason would not answer.

FORMER OCCUPATIONS.

Former occupations of the prostitutes in this group include the following: Hair-dressers and manicurists, 10; waitresses, 27; hospital nurses, 4 ; factory workers, I6; housewives, 4 ; seamstresses, I I ; servant girls, 60 ; stenographers, I6; department-store clerks, 40; telephone operators, 20; artificial flower makers, 7; laundry workers, 13 ; dance-hall entertainers, 6 ; milliners, 7 ; governesses, 3 ; convent student, I ; barber, I ; chorus girls, 19 ; highschool teacher, I.

REASONS FOR ENTERING LIFE OF PROSTITUTION.

The various reasons for entering life of prostitution as spontaneously given by the individuals of this group being:

"Easy money"; " thought her previous sex experience unfitted her for marriage"; " induced by other girls"; "language diffculty "; wanted clothes "; " put in business by husband "; " wanted sexual intercourse"; "did not like to work"; "good time"; "induced by men"; " to support child"; " curiosity"; " excitement"; " easiest way to make a living"; "imagined a gay life"; " fool, I guess"; " mother to support"; " deserted by husband"; " trouble"; "drifted from cabaret"; " thought was pregnant"; "pregnant and discouraged "; " too strict at home "; "induced by prostitutes"; " wanted nice things"; " seduced by employer"; 
"wages too low" (principal answer of factory girls, servant girls and clerks); " abuse at home"; "bad company"; " just happened "; "alcoholism"; " in debt"; "knew others in business"; "wanted money."

\section{ASSOCIATES.}

One hundred and forty-four or 43.75 per cent stated positively that their childhood associations were bad; 96 stated that their childhood associations were good; eight stated that they had no associates; the remainder stated that they had both good and bad or refused to answer.

\section{AMUSEMENTS.}

The various kinds of amusements appealing to this group, both as children and at present are: "Shows"; "dancing"; "roller skating"; " horseback riding"; "theater"; " music"; "fancy work"; "athletics" (several of this group being professional swimming girls); "just fool around"; "Sunday-school"; "parties"; " sewing"; " everything tough "; " eating "; "cafes"; "picking flowers "; " card games"; " picnics"; " dolls "; " excitement"; " reading novels"; " movies".

REASONS FOR LEAVING HOME.

"Dissatisfied with home "; "stepmother" (I I) ; "stepfather" (2); " mother dead" (2); " early marriage" (28); "orphan" (II) ; " to work" (36) ; " eloped" (2) ; " to enter house of prostitution" (9) ; "family quarrels" (20); "stage struck" (2) ; "needed money" (5); " to see life" (I); "pregnancy" (IO). One at $\mathrm{I} 2$ years; one at $\mathrm{I} 4$ years; two at $\mathrm{I} 5$ years; one at $\mathrm{I} 6$ years ; remainder older; " deserted by lover" (8); " direct from home" (9) ; " wanted to go to city" (9); " too large family" (I); " ran away" (II) ; "induced to leave by another girl" (I); "adoption" (I) ; "bad company" (I8); " poor home control" (I) ; "alcoholic father" (I); " to better herself" (I).

OCCUPATIONS OF MOTHERS.

Housewives; cooks ; waitresses ; trained nurse (I) ; dressmakers; clerks; laundress; boarding-house keepers; prostitutes (4); physician (I). 
FINANCIAL CONDITION OF PARENTS.

Seventy-one stated parents were very poor. Remainder stated parents were either in fair financial condition or provided well for their families. On being asked what they meant by being well provided it was ascertained homes (either farm or small homes in cities), plenty to eat and decent clothes. None stated parents were wealthy.

EDUCATION.

Sixteen per cent entered first year of high-school ; 46 per cent reached sixth grade; remainder gave definite evidence of being defective or subnormal. By subnormal we adopt Dr. Healy's conception of subnormal.

AGES OF FIRST SEXUAL EXPERIENCE.

It will be noted that the greatest number of inmates had their first sexual experience between the ages of 14 years and 18 years.

AGES AT WHICH ENTERED SPORTING LIFE.

Here it is observed that the greatest number enter the life of prostitution between the ages of 17 years and 22 years.

The graphic charts show this very well.

No attempt is here made to further analyze these figures except to mention that in a large percentage of juvenile delinquents improper sex experiences occur.

\section{E. Ophthalmological Data.}

The ophthalmological examination was made to check up the work on optic neuritis done by one of us (Thomas) as per published article in the American Journal of INSANITY, July, I9I 5 , "Optic Neuritis and the Color Fields in the Diagnosis of Syphilis, Hyperthyroidism, Neurasthenia, Dementia Præcox, Manic-Depressive Insanity, and Third Generation Syphilis."

The claim was made that many optic discs were classed as normal which were distinctly pathological, the principal point in the disc being the filling up of the normal excavation. This was found out by accident in noticing optic discs which had, when first observed, no excavation, and under treatment the excavation had reappeared.

Any toxic condition may produce this condition of filling up of the disc, and it is also noticed that the condition and degree of 
filling up, or swelling or cloudiness, changes from time to time, changing in intensity, as the patient may absorb or get rid of toxines. This may mean any infection, intestinal, appendicial, etc., tonsil or teeth infection, mineral poison, or most of ten syphilis.

The condition of the optic disc is a fairly reliable barometer in judging the condition of the nervous and circulatory system, the color or swelling of the discs and also the condition of the vessels whether the veins are dilated little or much and tortuous or angular and whether the arteries are tortuous or not.

Tyson and Clark in the Archives of Ophthalmology, July, 1912, published a résumé of their studies of Io9 cases of optic discs and vessels of dementia-præcox cases and give their summary as follows:

I. Congestion of discs; hyperemia and œdema; dilated and dark-colored veins; slightly contracted arteries, and blurring of the edges of the discs, all varying in degree. These changes constitute a low degree of perineuritis of the optic nerve.

2. Congestion of the nasal side and pallor of the temporal side, dilated veins and contracted arteries.

3. Pallor of the discs, dilated veins and contracted arteries. These changes constitute anemia and partial atrophy of the optic nerves. The more marked changes in the eye-syndrome were found in the more rapidly deteriorating types of dementia præcox.

In all these types (see chart) will be found various degrees of filling the Porus Opticus or the "P. O." for short. In Nos. I and 2 we may see a tiny dot of a P. O., or absent in one and hazy in the other. In the third variety there is rarely any sign of excavation; they are pale, yellowish pale, like a full moon on a slightly hazy night, and doughy. The condition has the appearance of a beginning atrophy, but atrophy is rarely seen. We have tried to distinguish them from the active neuritis cases; and in examining these cases the classification has been borne out by the neurological and physical examination. Many discs partake of both an active inflammation, with the D. P. type of disc. Many are border line. During the examination the neurologist would hazard his opinion as to the variety of discs the case would have and the ophthalmologist the variety of cases; whether " D. P." type or active syphilis, or the near-tabetic. We found the judgment on both sides was in the great majority of cases correct. We speak of the "D. P." type of discs; we find this classification covers the feeble-minded, 
imbeciles and idiots as well, and as all these cases are similar, merely a matter of degree of deterioration, they also blend one into the other and all classes have their " border lines."

The pathology of these cases has been corroborated by Dr. Myrtelle Canavan, ${ }^{2}$ pathologist to the Boston State Hospital for the Insane, in her report of $5^{8}$ cases of optic nerves examined, unselected. Forty had definite optic neuritis, and 18 of the 40 showed evidence of syphilis.

Dr. Clinton T. Cooke, of Seattle, Washington, also made an ophthalmoscopic examination of I5o dementia præcox and manic-depressives, a tabulation of which he presented at the Portland meeting of the Pacific Coast Oto-Ophthalmological Society in June, 1916.

His findings are a corroboration of the findings of Tyson and Clarke quoted before, and of Dr. Thomas's statement. Dr. Canavan's pathological findings certainly put the finishing word to it.

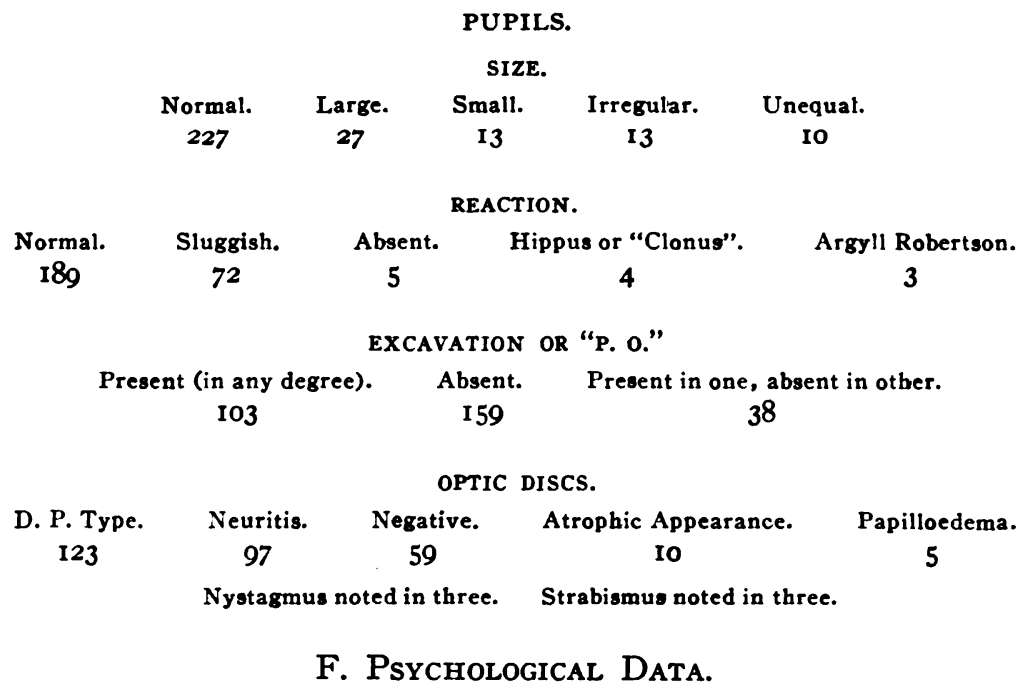

\section{F. Psychological Data.}

Under this caption we attempt to give the result of our observations extending over a period of 18 months. In other words, an attempt will be made to give you the same perspective as we have.

Looking back over our work of a year and a half, it is with no little difficulty that we set down our impressions of the social prob- 
lem of prostitution. The work extending over such a period of time, and visiting such a large number of houses, tended to wipe out all preconceived theories and notions about the subject. All these theories and notions in the popular mind arise from lack of knowledge and the hysterical and misleading statements sent out by well-meaning, but misinformed, enthusiasts, who, by edict, would make the world over in a night.

It particularly strikes us that everywhere the laws are directed against the woman. Granted that the women are unchaste, fallen, and undesirable in a community; it is the men who seek them out, and it is easily 20 to $I$, as not only our figures, but the statistics of others, demonstrate. Also that at least one-half of the visitors are married men.

If the problem of prostitution is to be attacked, something more will have to be done than chasing or shooing these unfortunates from pillar to post.

If you could have observed those streets and alleys by night as we did and have seen the army of men trailing up and down, in and out, like at a fair, it would illuminate the subject a little more.

The observations made inside the houses would also change your notions. Pitiable, yes, pitiable; for usually it meant simply young girls from homes of no training, of no innate strength of character, of little or no education, giving history of poor, of ten extremely bad, environmental conditions, of poor heredity, bad associates, the majority testing subnormal, many defective and feeble-minded and manifesting few or no special abilities, and many disabilities.

The especially educated, gifted, witty and sparkling ones, it was not our fortune to meet. We read of them, but seldom are they seen in houses of prostitution. They may be "kept women," and we hear of them in divorce and probate courts. We found no places where girls were kept against their wills, as most of the houses we visited were the so-called "cribs," nobody living in them except the "madame," the girls all having lodgings elsewhere and coming to work at certain hours and working under assumed names.

The term " white slave" is a very flexible one, and in the public mind is synonymous with all that is associated with prostitution. Certainly, in San Francisco, the police have kept pandering to a minimum, and unwilling detention in a house of prostitution is 
unknown, certainly, as a practice. No woman ever enters this life at the point of a pistol. The prostitute's life is usually easily deciphered, and we find the following picture the usual one: "Sexual experience" (sometimes numerous) preceding the actual "turning out"; "the decision to offer her body to indiscriminate intercourse with men for hire"; "the gratification of her ambition"; " the entering a house of prostitution and becoming a part of the "system.' " These women are the ones who in the shuffle of life dropped into their respective places as the various-sized oranges or pieces of crushed rock dropped through the apertures in the grader into their respective receptacles.

Their equipment is not sufficient to enable them to cope with any environment in a normal manner.

This is not alone a sociological problem but a psychological problem as well, and the studies of causes should begin in the cradle-the individual, male and female, should be studied, and those having special abilities should have them developed; those early manifesting bad sex habits should be guarded and if defective should become institutional cases.

A plea, then, for closer studies of our school children, an establishment by either public or private funds, of psychopathic laboratories for this work.

\section{Conclusions.}

Realizing that in our present state of educational and social development that a demand exists for prostitutes and that so long as the demand lasts, the supply will somehow be obtained, education, and proper early segregation of socially unfit of both sexes will be the ultimate solution if it can be called such. At present a vicious circle exists.

"As an economic, sociologic, eugenic, and medical problem, syphilis is occupying considerable attention at the present time. The source from which most of the syphilis originates is the house of prostitution. It is a place where syphilis is concentrated." It injures the germ plasm and offspring are often defective, again supplying the individuals who in turn become mere carriers for the spirochæta.

The facts as presented in this paper can be correlated into the following: 
To our minds they demonstrate the close unity between psychiatry and sociology, between venereal diseases and defective offspring; also that associated with syphilis we may have many perverted neurological symptoms hitherto overlooked; also that education, eliminating prudery, is essential to eliminate this evil. At the same time prophylactic measures should be more energetically taught to prevent spread of venereal diseases.

\section{OCCUPATION OF FATHERS}

\begin{tabular}{|c|c|c|}
\hline ation. & & Occupation. \\
\hline Shoe manufacturer $\ldots \ldots \ldots \ldots$ & $\mathbf{I}$ & $\cdots \ldots \ldots \ldots \ldots \ldots \ldots \ldots$ \\
\hline tone mason $\ldots \ldots \ldots \ldots \ldots \ldots$ & 5 & eman $\ldots \ldots \ldots \ldots \ldots \ldots \ldots$ \\
\hline rocer ....... & 3 & itect $\ldots \ldots \ldots \ldots \ldots \ldots \ldots$ \\
\hline employee & 7 & Clergyman $\ldots \ldots \ldots \ldots \ldots \ldots$ \\
\hline$\ldots \ldots$ & 1 & Scavenger $\ldots \ldots \ldots \ldots \ldots \ldots \ldots$ \\
\hline nith & 5 & $\ldots \ldots \ldots \ldots \ldots \ldots$ \\
\hline ngineer & 2 & $\ldots \ldots \ldots \ldots \ldots \ldots \ldots$ \\
\hline yman ... & I & Bank cashier $\ldots \ldots \ldots \ldots \ldots \ldots$ \\
\hline alesman .... & I & Gov. clerk ............ \\
\hline$\ldots$ & I5 & Bookbinder $\ldots \ldots \ldots \ldots \ldots$ \\
\hline$\ldots$ & 2 & Furrier $\ldots \ldots \ldots \ldots \ldots \ldots$ \\
\hline$\ldots \ldots$ & 3 & $\ldots \ldots \ldots \ldots \ldots \ldots \ldots \ldots \ldots$ \\
\hline nt . & 6 & Broker ............. \\
\hline er & I & Piano maker .............. \\
\hline or ... & 2 & -maker ... \\
\hline lerk ..... & 8 & Bricklayer ........ \\
\hline er & 2 & Reporter $\ldots \ldots \ldots \ldots \ldots \ldots \ldots$ \\
\hline ner ... & I & Farmer $\ldots \ldots \ldots \ldots \ldots \ldots \ldots$ \\
\hline er ... & 2 & Saloon-keeper $\ldots \ldots \ldots \ldots \ldots$ I3 \\
\hline ry worker & $\mathbf{I}$ & Innkeeper $\ldots \ldots \ldots \ldots \ldots$. \\
\hline er $\ldots$ & I & Barber $\ldots \ldots \ldots \ldots \ldots \ldots$ \\
\hline erk & $\mathbf{I}$ & Contractor $\ldots \ldots \ldots \ldots$ \\
\hline al flowe & I & Grain tester $\ldots \ldots \ldots \ldots \ldots$ \\
\hline 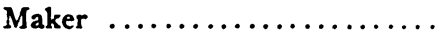 & I & Engineer (steam) ..... \\
\hline tsman & I & Miner $\ldots \ldots \ldots \ldots \ldots \ldots$ \\
\hline $\operatorname{lan}$ & 3 & Tailor ................. Io \\
\hline ian & 3 & Attorney ......... \\
\hline & 3 & Physician...$\ldots \ldots$. \\
\hline 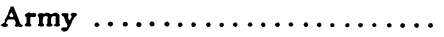 & 4 & Musician $\ldots \ldots \ldots \ldots \ldots$ \\
\hline an & 3 & Unknown $\ldots \ldots \ldots \ldots \ldots$ \\
\hline & , & Teacher $\ldots \ldots \ldots \ldots \ldots \ldots \ldots$ \\
\hline 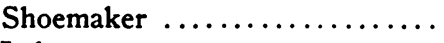 & & $\ldots \ldots \ldots \ldots \ldots \ldots$ \\
\hline er & & \\
\hline
\end{tabular}


AGES.

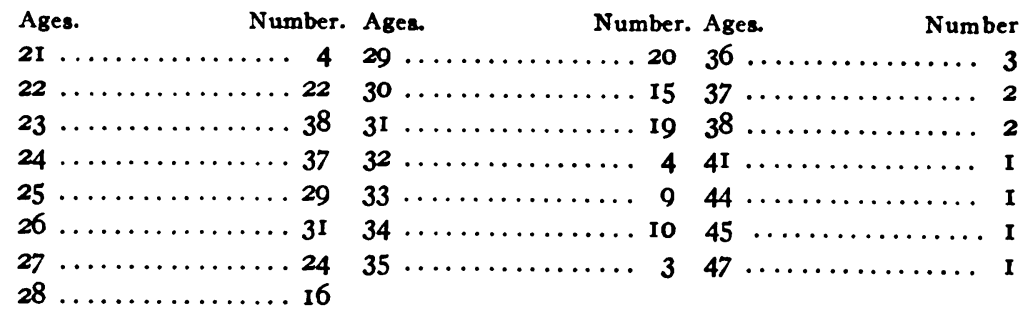

AGES AT WHICH FIRST SEXUAL EXPERIENCE OCCURRED. $\begin{array}{rrrrrrrrrrrrrrrrr}\text { Ages.... } & 12 & 13 & 14 & 15 & 16 & 17 & 18 & 19 & 20 & 21 & 22 & 23 & 24 & 25 & 26 & 27 \\ \text { No...... } & 6 & 4 & 21 & 25 & 32 & 28 & 31 & 11 & 3 & 5 & 1 & 2 & 1 & 1 & 0 & 1\end{array}$ 178 gave ages. Others either refused or did not remember.

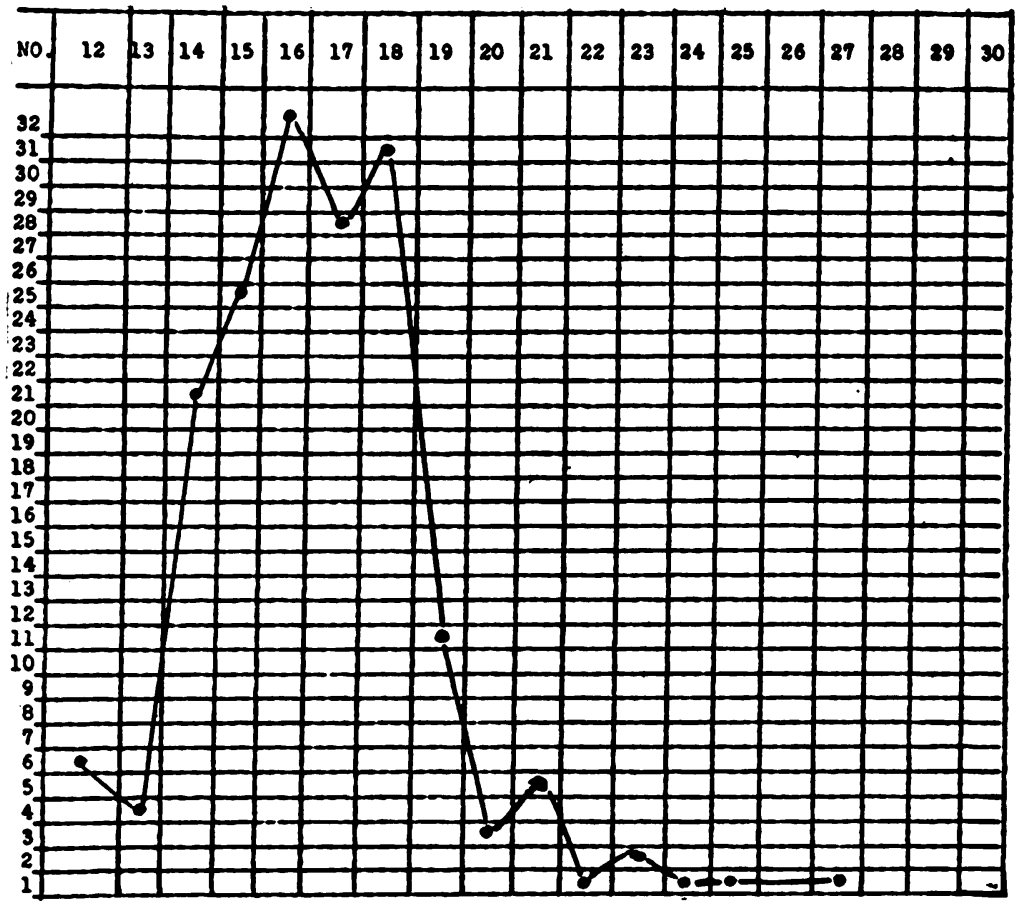

Ages at Which First Sexual Expertence Occurred. 
AGES AT WHICH ENTERED "SPORTING LIFE".

\begin{tabular}{|c|c|c|c|c|c|c|c|c|c|c|c|c|}
\hline $\begin{array}{l}\text { Ages................ } \\
\text { No................... }\end{array}$ & $\begin{array}{r}15 \\
6\end{array}$ & $\begin{array}{l}16 \\
16\end{array}$ & $\begin{array}{l}17 \\
29\end{array}$ & $\begin{array}{l}18 \\
45\end{array}$ & $\begin{array}{l}\text { I9 } \\
38\end{array}$ & $\begin{array}{l}20 \\
28\end{array}$ & $\begin{array}{l}21 \\
23\end{array}$ & $\begin{array}{l}22 \\
31\end{array}$ & $\begin{array}{l}23 \\
16\end{array}$ & $\begin{array}{l}24 \\
13\end{array}$ & $\begin{array}{l}25 \\
10\end{array}$ & \\
\hline $\begin{array}{l}\text { Ages } \ldots \ldots \ldots \ldots \ldots \ldots{ }^{27} \\
\text { No.......... }\end{array}$ & $\begin{array}{r}28 \\
6\end{array}$ & $\begin{array}{r}29 \\
2\end{array}$ & $\begin{array}{r}30 \\
2\end{array}$ & $\begin{array}{r}3 I \\
\text { I }\end{array}$ & $\begin{array}{r}32 \\
0\end{array}$ & $\begin{array}{r}33 \\
0\end{array}$ & $\begin{array}{r}34 \\
0\end{array}$ & $\begin{array}{r}35 \\
0\end{array}$ & $\begin{array}{r}36 \\
0\end{array}$ & $\begin{array}{r}37 \\
0\end{array}$ & $\begin{array}{r}38 \\
0\end{array}$ & \\
\hline
\end{tabular}

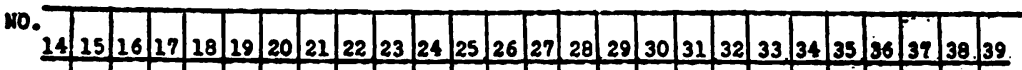

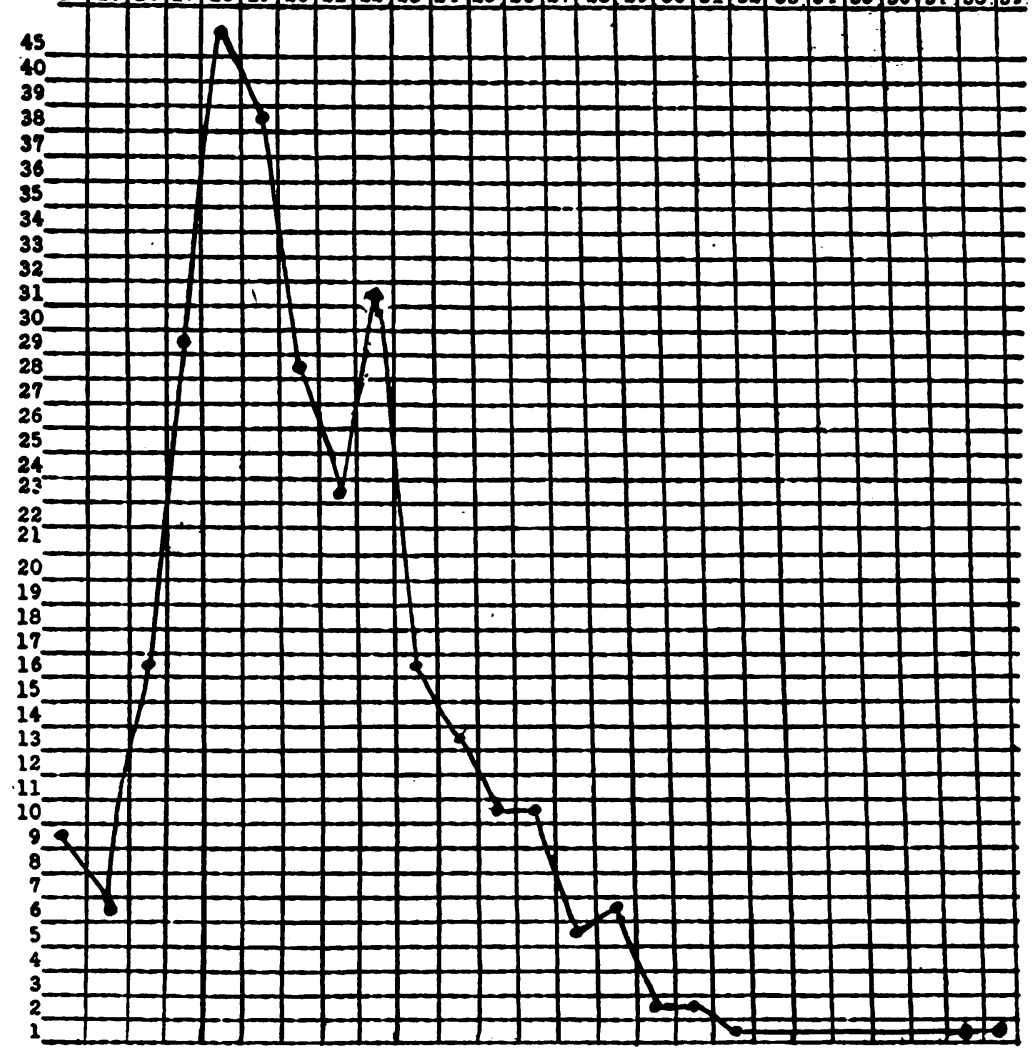

Ages at Which Entered “Sporting Life." 


\section{REFERENCES.}

1. Wassermann examinations were made in The Oakland Laboratory, Mabel Little, laboratory technician.

2. Histological Study of the Optic Nerves in a Random Series of Insane Hospital Cases-Myrtelle Canavan. Journal of Nervous and Mental Diseases, March, 1916.

3. The Appearance of the Fundus Oculi in General Paresis, ManicDepressive Insanity and Dementia Præcox-Clinton T. Cooke, Seattle. Transactions of the Pacific Coast Oto-Ophthalmological Society, June, I9I6.

4. W. W. Graves, St. Louis, “Scaphoid Scapulæ." Med. Record, May 21, I9I0. 